\title{
WORKER PROTECTION DURING MERCURY ELECTROLYSIS CELL PLANT DECOMMISSIONING*
}

\author{
Jean-Claude BESSON ${ }^{1}$, Estelle AUGARDE², and Michael NASTERLACK ${ }^{3}$ \\ Arkema, Saint-Fons ${ }^{1}$, Manosque ${ }^{2}$, France, BASF SE, Ludwigshafen ${ }^{3}$, Germany
}

Received in January 2012

CrossChecked in May 2012

Accepted in April 2012

\begin{abstract}
This article brings information on how to protect worker health during the decommissioning of mercurybased electrolysis facilities. It relies on the Euro Chlor document "Health 2, Code of practice, Control of worker exposure to mercury in the chlor-alkali industry" that provides protection guidelines for both normal production and decommissioning activities, and on hands-on experience gained during chlor-alkali plant decommissioning operations.

Decommissioning and dismantling of mercury-containing chlorine production plants presents challenges to industrial hygiene and health protection that are usually not present during normal operations. These involve meticulous training and enforcement of the appropriate use of personal protective equipment to prevent excessive mercury exposure.

The best practice guidelines and recommendations available from Euro Chlor can help employers and occupational physicians to manage these challenges, as they provide state-of-the-art procedures. Our experience is that rigorous implementation of these procedures and worker training ensured acceptable hygiene at the workplace and prevented mercury-related adverse health effects.
\end{abstract}

Key words: chlor-alkali industry, chlorine, industrial hygiene, medical surveillance

Chlorine production usually involves three processes using either mercury, diaphragm, or more recently, membrane technologies (1). Mercury has been used since the $19^{\text {th }}$ century, even though no new mercury plant has been built since the 1980s due to the hazards of mercury for human health and the environment. Euro Chlor, a professional organisation representing the European chlorine producers, has agreed a voluntary commitment with its members to shut down European chlor-alkali mercury electrolysis plants by 2020 at the latest. Further to this agreement, several plants have switched to the membrane process. At the same time, many mercury plants have been

\footnotetext{
* Partly presented at the $39^{\text {th }}$ International MEDICHEM Congress on Occupational and Environmental Health in the Production and Use of Chemicals "Occupational Health in a Changing World", Heidelberg, Germany, 2 - 5 June 2011
}

decommissioned and others will follow in the near future.

The aim of this article is to provide information on how to protect worker health during the decommissioning of mercury-based electrolysis facilities. It is based on the feedback from recently decommissioned plants, as Euro Chlor has not yet identified published data from decommissioning mercury electrolysis plants.

Mercury-based chlorine production plants use large amounts of mercury to produce chlorine; about $100 \mathrm{t}$ of mercury is used to produce $50,000 \mathrm{t}$ of chlorine. Heavy exposure is imminent unless workers use efficient means of prevention and protection (24).

In practice, occupational safety at mercury-based electrolysis plants has been improving steadily over 
the last decades, so much so that exposure to mercury and individual mercury body burden are usually kept below the applicable limits (5). However, exposure can be much higher during decommissioning than during normal production. The amount of mercury creating this exposure represents the "difference to balance", which is the difference between the quantity of mercury in the waste sent to deposit and in the products (chlorine, hydrogen, caustic soda) and the quantity of mercury added to the electrolysis cells in order to maintain a constant amount in the process. It may have been deposited on girders and other materials for decades, and only be mobilised during dismantling or decommissioning operations. At these moments, mercury air concentrations may exceed the Occupational Exposure Limit (OEL) of $20 \mu \mathrm{g} \mathrm{m}^{-3}$ by a factor of 10 to 20 .

The pattern of exposure is also different. During production, exposure is generally stable, while during decommissioning, exposure can vary significantly from one day to another. This puts a lot of strain on managing exposure.

The best way to assess mercury exposure in occupational medicine is by biomonitoring, where urinary mercury measurement is the method of choice. During normal operations, urinary mercury in workers slowly increases for several months until it reaches steady-state. During decommissioning, we once observed a result breaching limit values after only three working days.

Euro Chlor has published a document named "Health 2, Code of practice, Control of worker exposure to mercury in the chlor-alkali industry". It focuses on occupational health and industrial hygiene aspects in running mercury-based electrolysis plants (6). This article follows its structure and brings additional information and hands-on experience specific to decommissioning.

\section{Organisation and management}

Decommissioning is not simply destroying a plant; it must be planned properly. A written policy is required which includes a system for health management of mercury-related processes with continuous improvement as far as it is possible during the months, sometimes more than a year, necessary to remove everything that has been contaminated by mercury. Obviously, this policy for decommissioning is different from that used during production. It should contain the names, responsibilities and tasks of each technician, and their mobile phone numbers. It should also provide details about and responsibilities of the plant's physician and each contractor's physician.

Laboratories which measure mercury in air and urinary mercury should have high quality control procedures. They should participate in a national or international quality control scheme to maintain reliable results (7).

Regarding the medical department, a policy should be established to handle medical surveillance when the physician or nurse is absent due to holidays or for any other reason. Workers should know to whom to refer to in case of a problem.

\section{Health hazards and personal hygiene standards}

It is important to provide workers with sufficient information on mercury toxicity. Pregnant women must be excluded from work where there is a risk of exposure to mercury.

The risk of acute mercury exposure is usually not relevant while the electrolysis cells are running. During decommissioning however, this risk is real. One of the procedures that may involve high exposure is blowtorch cutting of steel that has been contaminated by mercury for years.

Chronic risk is under control in normally operating electrolysis plants in developed countries, as exposure is more or less stable. Again, decommissioning brings the risk of much higher and more varied exposure.

Workers should receive specific training in personal hygiene and adopt efficient working and housekeeping practices, including decontamination procedures. In exposed areas, workers should always wear proper work clothing. This includes disposable unwoven overalls. Our experience in several plants tells us that workers should change their overalls each time they stop working, which means two overalls in the morning and two in the afternoon. Obviously, work clothes should never be brought home but washed on site to ensure that wastewater is properly treated.

Changing facilities should be separated into "clean" and "dirty". Dining facilities should be located in clean areas. Additional facilities may be necessary for extra workers during the dismantling period. They should be designed to allow easy cleaning. All areas should be washed with bleach every day.

Smoking materials like cigarettes, pipes or tobacco should never be carried in work clothes, because they might become contaminated and lead to additional inhalatory mercury exposure, if smoked. 
Taking a shower is necessary at the end of each work shift, one before lunch and one at the end of the day.

Footwear should be impervious to mercury and resistant to corrosives such as caustic soda. Gloves should also be impervious to mercury and replaced on a regular basis; they should never be carried in the pockets; leather gloves are out of question. Respirators should be stored in a mercury-free environment and decontaminated properly after each use.

\section{Biomonitoring of mercury exposure}

The method of choice for individual monitoring of mercury exposure is the determination of mercury in urine, adjusted to urinary creatinine concentration (8). Mercury in ambient air cannot reliably predict individual mercury uptake (5). Mercury in blood mainly reflects organic mercury uptake, primarily resulting from dietary exposure to fish (9).

Workers should be taught how to give urine samples and should be aware of exposure limits, medical surveillance programme, and biological monitoring. During decommissioning, they should receive each urine test result with a medical comment.

Urinary mercury should be tested more often during decommissioning than during production due to the higher level of exposure. Weekly testing is recommended, not only for personnel working in the cell rooms, but also for those handling contaminated waste.

Samples should be taken at approximately the same time of the day. A sample taken before starting work or after showering at the end of a shift is preferred to minimise the risk of sample contamination.

Baseline testing is necessary before decommissioning begins and the last test should take place after decommissioning activities are over to see whether workers have ever been overexposed between these two time points.
Table 1 shows courses of action related to the measured mercury urinary levels during normal plant operation and decommissioning.

More rigorous rules recommended in the latter case take into account the possibility of a very quick increase in urinary mercury levels. For example, with a weekly monitoring frequency, a case has been observed where, starting from a level below $35 \mu \mathrm{g}$ $\mathrm{g}^{-1}$ creatinine, one week later the urinary mercury excretion had increased to $105 \mu \mathrm{g} \mathrm{g}^{-1}$ creatinine. An early intervention performed in this case most likely helped to prevent strong mercury effects. Clinical signs of mercury exposure do not usually occur in workers with urinary mercury below $300 \mu \mathrm{g} \mathrm{L}{ }^{-1}$, except in case of renal disease (10). This level corresponds to around $200 \mu \mathrm{g} \mathrm{g}^{-1}$ creatinine, as urinary creatinine is generally around $1.5 \mu \mathrm{g} \mathrm{L}^{-1}(0.3 \mu \mathrm{g} \mathrm{L}-1$ to $\left.3 \mu \mathrm{g} \mathrm{L}^{-1}\right)$. A new worker would reach the level of $25 \mu \mathrm{g} \mathrm{g}^{-1}$ creatinine after six to 15 weeks of exposure and the level of $35 \mu \mathrm{g} \mathrm{g}^{-1}$ creatinine between nine and 33 weeks. In all our cases, the results dropped below $35 \mu \mathrm{g} \mathrm{g}^{-1}$ creatinine soon after the end of exposure.

\section{Monitoring mercury in air}

Eight-hour urinary measurements should be performed according to European regulation. Results are to be expressed as time-weighted average and compared to the OEL of $20 \mu \mathrm{g} \mathrm{m}^{-3}$ (11).

Because systematic measurements during a demolition process are difficult to perform and unexpected exposure to mercury can happen, it is advisable to have portable equipment to do frequent spot measurements of mercury concentration in air.

These measurements proved to be most helpful in practice. Air mercury was measured three times a day. As expected, it would increase by the afternoon (Figure 1) and was also higher on sunny than on cloudy days. In fact, air mercury levels correlated with the temperature recorded at the nearby weather station (Figure 2).

Table 1 Action requirements according to urinary mercury findings

\begin{tabular}{|c|c|c|}
\hline \multicolumn{2}{|c|}{ Urinary mercury / $\mu \mathrm{g} \mathrm{g}^{-1}$ creatinine } & \multirow{2}{*}{ Management action } \\
\hline Normal operation (ref. 6) & Decommissioning & \\
\hline$<30$ & $<25$ & no action \\
\hline 30 to 50 & 25 to 35 & review of employee work practice \\
\hline$>50$ & $>35$ & $\begin{array}{l}\text { remove from exposure to mercury } \\
\text { until below } 30 \mu \mathrm{g} \mathrm{g}^{-1} \text { creatinine }\end{array}$ \\
\hline
\end{tabular}




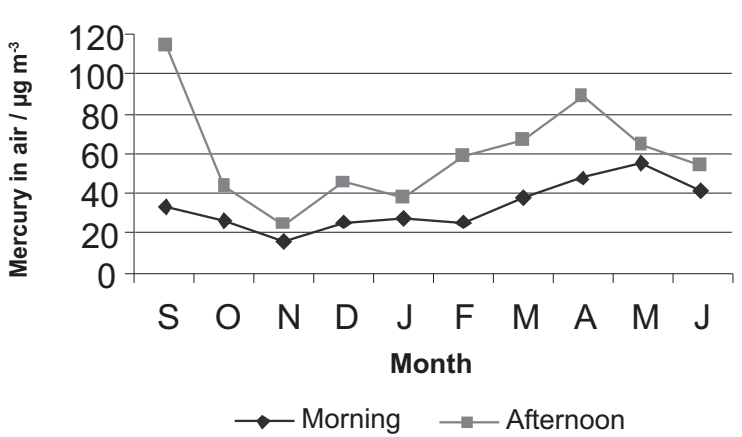

Figure 1 Morning and afternoon mercury air concentrations measured over the ten months of decommissioning in 2007-2008

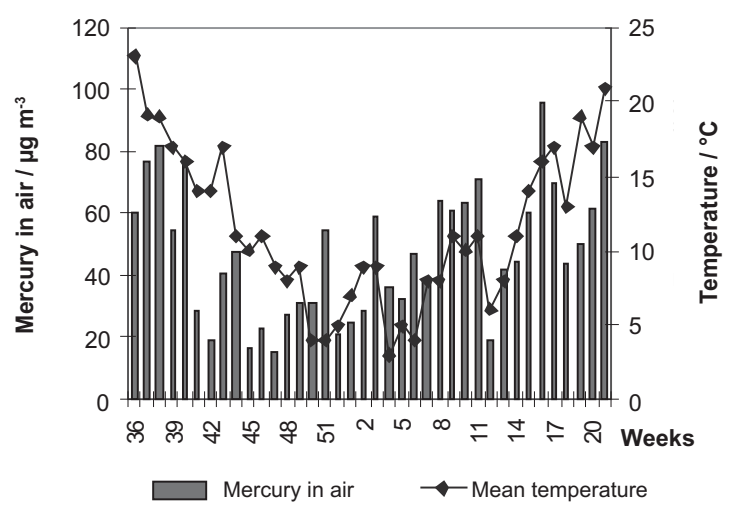

Figure 2 Mercury air concentrations and mean temperature over the ten months of decommissioning (Weeks $=$ week of the year)

Thanks to these observations, the work shift was rescheduled to begin at 5 a.m. and end early to avoid the hottest hours. To explain this organisational change the workers were presented with the mercury air measurements.

Further to these observations, it is recommended not to do decommissioning during the summer, or at least avoid activities with the highest exposure potential.

In addition, mercury air measurements have shown that mercury levels rise with the number of decommissioning operators who happen to stir it up with their activity. Therefore each area has a limitation put on the number of workers allowed.

\section{Risk assessment and management}

Each step of dismantling has to be assessed, in particular the differences from regular production. As some activities have a higher exposure potential than others, the plant management should make sure that the workers are aware of these. This particularly refers to cutting with a blowtorch, whereas washing presents the lowest exposure risk.

The first assessment of the contamination should involve examination of the area for mercury droplets. Washing the most contaminated places usually requires large amounts of water. Covering mercury with water is useful as it limits evaporation.

What follows risk assessment is taking precautions to protect workers. As a rule, the use of personal protective equipment will be indispensable in several dismantling operations. However, without an efficient prevention plan, personal protective equipment may not be sufficient. This plan should be published in an understandable way and available to all.

\section{Health examination and health-related actions in case of overexposure}

Exposure to high levels of inorganic mercury vapour mainly results in nephrotoxicity and neurotoxicity $(12,13)$. Occupational medical surveillance should be sensitive enough to detect early signs of toxicity in these organ systems.

At pre-placement examination, the examining physician has to be aware that the worker will be exposed to mercury. The aim of this examination is to establish the baseline levels for new workers and for third-party contractors. In some cases, a contracted company could be specialised in demolition, and the workers may have been exposed to mercury before without knowing it.

Beside the regular medical examination and tests, the baseline examination should include urinary mercury analysis and the history or clinical signs of renal insufficiency and neurological or psychiatric disturbances as exclusion criteria. In the EU, urine mercury levels in occupationally unexposed persons are usually less than $5 \mu \mathrm{g} \mathrm{g}^{-1}$ creatinine (14).

Similar to biomonitoring, the last examination after dismantling operations are over is to establish whether there are signs of mercury toxicity.

Between these two time points, examination is due whenever overexposure is suspected or documented. The first objective of this intermittent examination is to establish the current health status of the exposed person. The second is to provide a new information to the affected person by the physician or the nurse. The third objective is to discuss the real working conditions in a one-on-one conversation with the worker in order to identify potential shortcomings in the current operations which the worker might otherwise address in the presence of a manager. 


\section{Information, training, record keeping, and auditing}

The training should address all the topics covered so far. Results from the audits should also be communicated to the workers. This should be done using a language and in a way understandable to all the workers. It should be repeated in case of overexposure or modification of the working process.

Every worker should sign a training participation list, which is to evidence that all decommissioning workers have been properly informed of the exposure risks and countermeasures.

Records should be kept for medical surveillance, for future medical research, and for handling insurance claims or lawsuits for several decades. They should be organised so that an outside body could understand how the processes were managed. The knowledge related to the hazards, hygiene, biomonitoring, and risk assessment is so valuable that it should not fade when all European mercury electrolyses have been decommissioned.

At least an internal audit system is necessary to monitor and continuously improve the working conditions. The Euro Chlor document Health 6, Audit questionnaire mercury is being updated to take include the specificities of dismantling operations (15).

\section{CONCLUSION}

Decommissioning and dismantling of mercurycontaining chlorine production plants poses to industrial hygiene and health challenges usually not present during normal operations. The best practice guidelines and recommendations available from Euro Chlor help employers and occupational physicians to manage these challenges through state-of-the-art procedures. Experience gathered during decommissioning operations has confirmed that rigorous implementation of procedures and communication with the involved workers successfully maintained acceptable workplace hygiene and helped to avoid mercury-related adverse health effects.

\section{Acknowledgements}

We thank Jean-Pol Debelle and Shaun Presow, both from Euro Chlor, for their helpful comments and support in preparing this manuscript.

\section{REFERENCES}

1. European Commission: Integrated Pollution Prevention and Control (IPPC) - Reference Document on Best Available Techniques in the Chlor-Alkali Manufacturing Industry December 2001 [displayed 27 April 2012]. Available at http://eippcb.jrc.es/reference/_referenceDetailsBATIS. $\mathrm{cfm} ? \mathrm{twg}=\mathrm{cww} \& \mathrm{ID}=8793$

2. World Health Organization (WHO). Inorganic Mercury. International Programme on Chemical Safety, Environmental Health Criteria 118. Geneva: WHO; 1991.

3. International Agency for Research on Cancer (IARC). Mercury and mercury compounds. In: IARC Monographs on the Evaluation of Carcinogenic Risks to Humans, Beryllium, Cadmium, Mercury and Exposures in the Glass Manufacturing Industry. Vol. 58. Lyon: IARC; 1993. p. 239-345.

4. OSHA Directive CPL 02-02-006: "Inorganic Mercury and its Compounds" [displayed 27 April 2012]. Available at http://www.osha.gov/pls/oshaweb/owadisp.show document?p_id=1573\&p_table=DIRECTIVES

5. Bender HF, Beziel M, Krehenwinkel H, Lademann H, Münstedt R, Menig H, Will W, Nasterlack M. [Korrelation zwischen inhalativer $\mathrm{Hg}$-Aufnahme und $\mathrm{Hg}$-Ausscheidung, in German]. Gefahrstoffe Reinhalt Luft 2006;66:465-8.

6. Euro Chlor: Code of practice, control of worker exposure to mercury in the chlor-alkali industry, HEALTH $2,5^{\text {th }}$ edition, November 2008 (http://www.eurochlor.org/safetytechnology/all-technical-publications/document-search. aspx?ref=Health\%202)

7. Schaller KH, Angerer J, Drexler H. Quality assurance of biological monitoring in occupational and environmental medicine. J Chromatogr B Analyt Technol Biomed Life Sci 2002;778:403-17.

8. Will W, Kuhn H, Lange A, Guth J. [Belastung und Beanspruchung bei Quecksilberexposition durch Bausanierung, in German]. Arbeitsmed Sozialmed Umweltmed 2006;41:159.

9. Brune D, Nordberg GF, Vesterberg O, Gerhardsson L, Wester PO. A review of normal concentrations of mercury in human blood. Sci Total Environ 1991;100:235-82.

10. Lauwerys R. [Toxicologie industrielle et intoxications professionnelles, in French]. Paris: Masson; 1991.

11. Commission Directive 2009/161/EU of 17 December 2009 establishing a third list of indicative occupational exposure limit values in implementation of Council Directive 98/24/EC and amending Commission Directive 2000/39/EC (Text with EEA relevance) [displayed 27 April 2012]. Available at http://eur-lex.europa.eu/LexUriServ/LexUriServ.do?uri=OJ: L:2009:338:0087:0089:EN:PDF

12. Clarkson TW, Magos L, Myers GJ. The toxicology of mercury - current exposures and clinical manifestations. N Engl J Med 2003;349:1731-7.

13. Deutsche Forschungsgemeinschaft (DFG), editor. [Gesundheitsschädliche Arbeitsstoffe - Toxikologischarbeitsmedizinische Begründungen von MAK-Werten, 48. und 49. Lieferung, in German]. Winheim: Wiley-VCH; 2010.

14. Stellungnahme der Kommission „Human-Biomonitoring“ des Umweltbundesamtes. [Aktualisierung der Referenzwerte für Blei, Cadmium und Quecksilber im Blut und im Urin von Erwachsenen, in German]. Umweltmed Forsch Prax 2004;9:377-8.

15. Euro Chlor. HEALTH 6 - Audit Questionnaire Mercury. $2^{\text {nd }}$ edition, March 2006 [displayed 27 April 2012]. Available at http://www.eurochlor.org/safety-technology/all-technical$\mathrm{p} \mathrm{u} \mathrm{b} \mathrm{l} \mathrm{i} \mathrm{c} \mathrm{a} \mathrm{t} \mathrm{i} \mathrm{o} \mathrm{n} \mathrm{s/do} \mathrm{c} \mathrm{u} \mathrm{m} \mathrm{e} \mathrm{n} \mathrm{t} \mathrm{-} \mathrm{s} \mathrm{e} \mathrm{a} \mathrm{r} \mathrm{c} \mathrm{h.}$ aspx?ref=HEALTH $\% 206 \% 20$ 


\section{Sažetak}

\section{ZAŠTITA RADNIKA TIJEKOM GAŠENJA POGONA ZA ELEKTROLIZU POMOĆU ŽIVE}

Cilj je ovoga rada pružiti informacije o načinu na koji se može zaštititi zdravlje radnika kod gašenja pogona u kojima se obavlja elektroliza pomoću žive. U ovu je svrhu korišten dokument Euro Chlor-a Zdravlje 2, Pravilnik, Kontrola izloženosti živi kod radnika koji rade u kloralkalnoj industriji (eng. Health 2, Code of practice, Control of worker exposure to mercury in the chlor-alkali industry) kao podloga: navedeni se dokument odnosi na redovitu proizvodnju, ali i na aktivnosti gašenja pogona. Preporuke koje su ovdje dane podupiru i iskustva koja su stečena i prikupljena tijekom radnji gašenja kloralkalnih postrojenja. Gašenje i rastavljanje klornih proizvodnih postrojenja koja sadrže živu izazovi su za higijenu rada i zdravlje koji inače ne postoje kod redovitih poslova. Ako ne postoji odgovarajuća izobrazba u svezi s korištenjem odgovarajuće zaštitne opreme te ako se takve mjere ne provode rigorozno, može doći do prekomjernoga izlaganja živi.

Smjernice i preporuke za najbolju praksu koje se nalaze na stranicama Euro Chlor-a mogu pomoći poslodavcima i liječnicima medicine rada u suočavanju s navedenim izazovima. Pri tome im stoje na raspolaganju vrhunski suvremeni postupci. Naše osobno iskustvo stečeno tijekom gašenja takvih postrojenja navelo nas je na zaključak da stroga provedba ovakvih postupaka uz odgovarajuću komunikaciju s radnicima omogućuje održavanje primjerene higijene na radnom mjestu i sprječava nuspojave vezane za živu.

KLJUČNE RIJEČI: higijena rada, kloralkalna industrija, klor, zdravstveni nadzor

\section{CORRESPONDING AUTHOR:}

Jean-Claude Besson, MD

Arkema

P. O. Box 35, Saint-Fons, F-69191, France

E-mail: jean-claude.besson@arkema.com 